\title{
Expression of MRP14 gene is frequently down-regulated in Chinese human esophageal cancer
}

\author{
Jie WANG ${ }^{1^{*}}$, Yan $\mathrm{CAI}^{1^{*}}$, Hao XU ${ }^{1}$, Jun $\mathrm{ZHAO}^{2}$, Xin $\mathrm{XU}^{1}$, Ya Ling $\mathrm{HAN}^{1}$, Zhi Xiong $\mathrm{XU}^{1}$, Bao Sheng \\ CHEN $^{1}$, Hai HU ${ }^{1}$, Min WU ${ }^{1}$, Ming Rong WANG ${ }^{1 * *}$ \\ ${ }^{1}$ National Laboratory of Molecular Oncology, Cancer Institute (Hospital), Chinese Academy of Medical Sciences, \\ Peking University of Medical School, Beijing 100021, China. \\ ${ }^{2}$ Department of Thoracic Surgery, Cancer Institute (Hospital), Chinese Academy of Medical Sciences, Peking \\ University of Medical School, Beijing 100021, China.
}

\begin{abstract}
Migration inhibitory factor-related protein 14 (MRP14) is one of calcium-binding proteins, referred as S100A9. The heterodimeric molecule formed by MRP14 with its partner MRP8 (S100A8) is the major fatty acid carrier in neutrophils. The MRP8/14 complex has been also implicated in the intracellular transport of arachidonic acid and its precursors in keratinocytes. We show here the involvement of MRP14 in human esophageal cancer. In an initial study, mRNA differential display - reverse transcription polymerase chain reaction (DD-PCR) was performed with two esophageal carcinomas, one esophageal adenocarcinoma and matched normal adjacent mucosa. DD-PCR with the arbitrary primer OPA3 showed that one cDNA band was highly expressed in normal tissues, but disappeared or substantially decreased in tumor counterparts. It was later identified to be the 3'-end of migration inhibitory factor-related protein 14 (MRP14). Northern blotting, RT-PCR and Western blotting corroborated the down-regulation of MRP14 in 58/64 squamous cell carcinomas and 2/2 adenocarcinomas as compared with adjacent normal epithelia of the esophagus. MRP14 was undetectable in 3/3 esophageal-carcinoma cell lines. Immunochemistry demonstrated that expression of MRP14 was restricted to normal esophageal epithelia. No mutation was found in the genomic DNA of the MRP14 gene by PCR and directed DNA sequencing. Our finding suggested that the reduction of MRP14 expression is a frequent event in Chinese human esophageal cancer.
\end{abstract}

Keywords: esophagus, carcinoma, MRP14, S100A9.

\section{INTRODUCTION}

Esophageal cancer is a common malignant solid tumor of digestive system. It ranks the fourth cause of cancer death in China and among the 10 most frequent cancers in the world $[1,2]$. Mortality rates of esophageal cancer are very close to incidence rates. Mutation, loss and abnormal expression of some candidate genes, such as Cyclin D1, $R b, p 53$ and $p 16$, were detected in esophageal cancer [3$6]$. However, few genes specially related to the disease has been found until now. Further searching for esophageal cancer-associated genes remains to be done for revealing the molecular and genetic basis of cancer development and progression.

In order to isolate the differentially expressed genes between esophageal carcinomas and normal epithelia of esophagus, we performed messenger RNA differential dis-

\footnotetext{
"These authors contributed equally to this work.

**Corresponding author: Ming Rong WANG

Tel: 86-10-67781331-8425, Fax: 86-10-67723790,

E-mail:wangme@263.net.cn
}

play reverse transcription - polymerase chain reaction (DDPCR). Herein we report our findings that expression of MRP14 significantly decreased in human esophageal carcinomas as compared with the matched normal adjacent mucosa.

\section{MATERIALS AND METHODS}

\section{Sample collection}

Fresh tumor tissues and matched adjacent normal mucosa were obtained at surgery. 13 cases were collected by the Pathology Department of Anyang Cancer Hospital, Henan Province, China, and the others, from Cancer Hospital, Chinese Academy of Medical Sciences, Beijing, China. Primary tumor regions and corresponding adjacent normal esophageal mucosa from the same patients were separately excised by experienced pathologists, and immediately placed in liquid nitrogen until use.

\section{Cell lines and cell culture}

Esophageal carcinoma cell lines, EC109, EC8712 and EC9706, were established in our laboratory[7-9]. The cell lines were main 
tained in M199 medium with $15 \% \mathrm{FCS}$ and cultured at $37^{\circ} \mathrm{C}, 5 \%$ $\mathrm{CO}_{2}$

\section{RNA extraction and cDNA synthesis}

Tumor samples were gross-dissected to trim away non-tumor tissues, and matched adjacent normal mucosa was separated from underlying muscle layers. Total RNA was prepared using Trizol reagent (Gibco) according to the manufacturer's instructions. RNA was treated with DNase I for $30-40$ min at $37^{\circ} \mathrm{C}$, extracted with phenol/isopropanol, precipitated in $3 M \mathrm{NaAc}(\mathrm{pH} 5.2)$ overnight at $4^{\circ} \mathrm{C}$, and dissolved in DEPC-treated water. $5 \mu \mathrm{g}$ of each RNA was reverse transcribed with 200 units Superscript II reverse transcriptase (Gibco) in the presence of $50 \mu M 3$ '-anchored oligo (dT) primer in 20 $\mu 1$ RT buffer $(1 \times$ PCR buffer, $2.5 \mathrm{mM} \mathrm{MgCl}, 10 \mathrm{~m} M$ DTT, $0.5 \mathrm{~m} M$ dNTP), at $65^{\circ} \mathrm{C}$ for $5 \mathrm{~min}$, followed by cooling to $37^{\circ} \mathrm{C}$ for $10 \mathrm{~min}$. Reverse transcriptase was inactivated at $70^{\circ} \mathrm{C}$ for $15 \mathrm{~min}$

\section{mRNA differential display}

mRNA differential display (DD-PCR) was performed with a modification of the procedure described by Liang and Pardee [10] Briefly, PCR amplification was done using $1 \mu 1$ of the cDNA, primed with mixed anchored primers (GT15N, N=A, C and G, equal mole) and a 10-mer arbitrary primer (Operon). The cycle parameters were $94^{\circ} \mathrm{C}$ for $4 \mathrm{~min}, 39^{\circ} \mathrm{C}$ for $4 \mathrm{~min}, 72^{\circ} \mathrm{C}$ for $2 \mathrm{~min}$, and then 35 cycles of $95^{\circ} \mathrm{C}$ for $20 \mathrm{~s}, 39^{\circ} \mathrm{C}$ for $2 \mathrm{~min}, 72^{\circ} \mathrm{C}$ for $1 \mathrm{~min}$. A final extension was carried out at $72^{\circ} \mathrm{C}$ for $5 \mathrm{~min}$. The resultant products were run on an $8 \%$ polyacrylamide gel electrophoresis and showed by silver staining. Identified bands were excised from the gel, and the cDNA was recovered by incubation at $37^{\circ} \mathrm{C}$ in $0.1 \times \mathrm{TE}$ overnight.

\section{Cloning and sequencing of differential display cDNA}

PCR-amplified cDNA were cloned into the pGEM-T easy vector (Promega). Plasmid DNA was prepared by using Wizard Miniprep Purification System (Promega). The sequence reactions were performed by TaKaRa Corp (Dalian city, China).

\section{Northern blot analysis}

Total RNA was denatured in the presence of $50 \%(\mathrm{vol} / \mathrm{vol})$ and $2.2 \mathrm{M}$ formaldehyde, subjected to electrophoresis on $1.2 \%$ agarose/ formaldehyde gel. Following electrophoresis, the RNA was transferred to nylon membranes (Bio-Rad) by capillary transfer in $10 \times \mathrm{SSC}$. Northern blots were prehybridized for $1 \mathrm{~h}$ in $1 M$ EDTA, $0.25 \mathrm{M}$ $\mathrm{Na}_{2} \mathrm{HPO}_{4}(\mathrm{pH} 7.2)$ and $7 \%$ SDS at $65^{\circ} \mathrm{C}$. The probe was prepared by Prime-a-Gene Labeling system in the presence of $\left[{ }^{32} \mathrm{P}\right]-\mathrm{dATP}$ and $\left[{ }^{32} \mathrm{P}\right]$-dCTP. Hybridization was carried out at $65^{\circ} \mathrm{C}$ for $18 \mathrm{~h}$, and blots were washed first for $20 \mathrm{~min}$ in $1 \mathrm{~m} M$ EDTA, $40 \mathrm{mM} \mathrm{Na} \mathrm{HPO}_{4}$, $5 \%$ SDS at $65{ }^{\circ} \mathrm{C}$, followed by wash in $1 \mathrm{~m} M$ EDTA, $40 \mathrm{mM}$ $\mathrm{Na}_{2} \mathrm{HPO}_{4}, 1 \%$ SDS. Then the membrane was autographed at $-70^{\circ} \mathrm{C}$ for $16 \mathrm{~h}$.

\section{RT-PCR detection}

The primers were designed according to the sequences of MRP14 and MRP 8 mRNAs (GenBank No.: NM 002965 and NM 002964). The sense primer for MRP14 was 5'-CAGCTGG AACGCAACATAGA-3' and the antisense primer, 5'-CCACAGCCAAGACA-
GTTTGA-3'. The sense/antisense primers for $M R P 8$ were 5'TCTTGTCAGC-TGTCTTTCAGAAG-3' and 5'CAGCCTCTGGGCATAACTC-3' repectively. $5 \mu \mathrm{g}$ of total RNA was used to synthesize the first strand of cDNA using superscript II (Gibco). The PCR amplification was carried out in $15 \mu$ l reaction volume

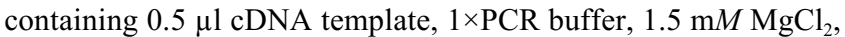
$200 \mathrm{~m} M$ dNTPs, $0.5 \mu M$ primer, and 1 unit Taq polymerase. After a 4 min denaturation at $94^{\circ} \mathrm{C}$, PCR was performed for 28 cycles. Each cycle consisted of $94^{\circ} \mathrm{C}$ for $30 \mathrm{~s}, 60^{\circ} \mathrm{C}$ for $30 \mathrm{~s}$ and $72^{\circ} \mathrm{C}$ for $1 \mathrm{~min}$, followed by a $72^{\circ} \mathrm{C}$ elongation for $6 \mathrm{~min} .5 \mu \mathrm{l}$ of each PCR product was electrophoresised on a $1.5 \%$ agarose gel. $\beta$-actin or $G A P D H$ was meantime amplified as control with the same templates. The upstream/downstream primers of $\beta$-actin was 5'-CGTGGACATCCGTAAAGACC-3' and 5'-ACATCTGCTGGAAGG TGGAC-3', and those of GAPDH, 5'-GACCACAGTCCATGCCATC-3' and 5'-ACCAGG AAATGAGCTTGACA-3'. The expected PCR products of MRP14, MRP8, $\beta$-actin and GAPDH were $475 \mathrm{bp}, 353 \mathrm{bp}, 209 \mathrm{bp}$ and $416 \mathrm{bp}$, respectively.

\section{Western blot analysis}

Tissues were disrupted with a cocktail of $8 \mathrm{M}$ urea, $4 \%$ CHAPS, $40 \mathrm{~m} M$ Tris, $1 \mathrm{~m} M$ PMSF, $20 \mathrm{~m} M$ spermin, $2 \mu \mathrm{g} / \mathrm{ml}$ aprotinin, $2 \mathrm{~m} M$ tetrabutylammonium phosphate, Carrier Ampholyte, DNase I and RNase. Lysate was kept on ice $1 \mathrm{~h}$ before centrifugation at 12,000g for $30 \mathrm{~min}$. The supernatants were transferred to Eppendorf tubes, stocking at $-70^{\circ} \mathrm{C}$ until use. Bradford method was used to assay the proteins concentration.

Total protein $(40 \mu \mathrm{g})$ was run on $12 \%$ SDS-polyacrylamide gels and then transferred to nitro cellulose membranes. Blots were blocked overnight and probed with affinity purified polyclonal antibodies against MRP14. After washed, the blots were incubated with horseradish peroxidase- conjugated secondary antibodies and visualized with the Amersham enhanced chemiluminescence ECL system.

\section{Immunohistochemistry}

A protein produced by prokaryotic expression was used to immunize rabbits to obtain a polyclonal antiserum to MRP14. The resulting high titer antiserum was employed as a primary antibody to stain formalin-fixed and paraffin-embedded sections of esophageal carcinomas. The immunohistochemistry signals were visualized with a peroxidase-linked assay system (ZYMED). Hematoxylin was used as a counterstain.

\section{Mutation analysis-Direct DNA sequencing}

The promotor region, the first exon and the upstream part of the first intron of the MRP14 gene were amplified by two pairs of primers: P1a. 5'-CCCCAAATCTCACCCTATGA-3' (position 489), P1b. 5'-CCACACAGAGTGTTTGCCAG-3' (position +15), and P2a. 5'-TATAAATGCCGAGCCTGCAC-3' (position -30), P2b. 5'-GCCCCAGCTTCACAG AGTATT-3' (position +512). Polymerase chain reactions were performed in a $50 \mu \mathrm{l}$ volume containing $10 \mathrm{~m} M$ Tris- $\mathrm{HCl}, \mathrm{pH} 8.3,50 \mathrm{~m} M \mathrm{KCl}, 1.5 \mathrm{~m} M \mathrm{MgCl}_{2}, 50 \mu M$ dNTPs, a $0.4 \mu M$ concentration of each primer, $100 \mathrm{ng}$ of genomic DNA, and 5 unit of pyrobest (Takara, Japan) DNA polymerase. After a 10 min denaturation at $95^{\circ} \mathrm{C}, \mathrm{PCR}$ was performed for 35 cycles. Each cycle consisted of $94^{\circ} \mathrm{C}$ for $30 \mathrm{~s}, 60^{\circ} \mathrm{C}$ for $30 \mathrm{~s}$ and $72^{\circ} \mathrm{C}$ for $45 \mathrm{~s}$, followed by a $72^{\circ} \mathrm{C}$ elongation for $5 \mathrm{~min} .2 \mu \mathrm{l}$ of each PCR product was electrophoresised on a $1 \%$ agarose gel. PCR fragments 
were purified by Wizard PCR preps DNA purification system (Promega), then were sequenced with the ABI PRISM BigDye terminator cycle sequencing ready reaction reagent set according to the manufacturer's recommendations in conjunction with an ABI PRISM 377 DNA sequencer.

\section{RESULTS}

\section{Differential expression of MRP14 mRNA between esophageal carcinomas and adjacent normal esoph- ageal mucosa}

Differential display was performed on RNAs isolated from esophageal carcinomas and adjacent normal esophageal mucosa. In order to minimize false positive of differential display, three cases of specimens were simultaneously analyzed. Only those bands consistently altered in all three cases were further investigated. With the arbitrary primer OPA3, one cDNA band of about $120 \mathrm{bp}$ was found barely expressed in cancer tissues while highly expressed in matched adjacent normal mucosa (Fig 1). The identified band were recovered, reamplified, cloned and sequenced. Databases searching showed that this cDNA fragment was the 3 '-end of migration inhibitory factorrelated protein 14 gene (MRP14).
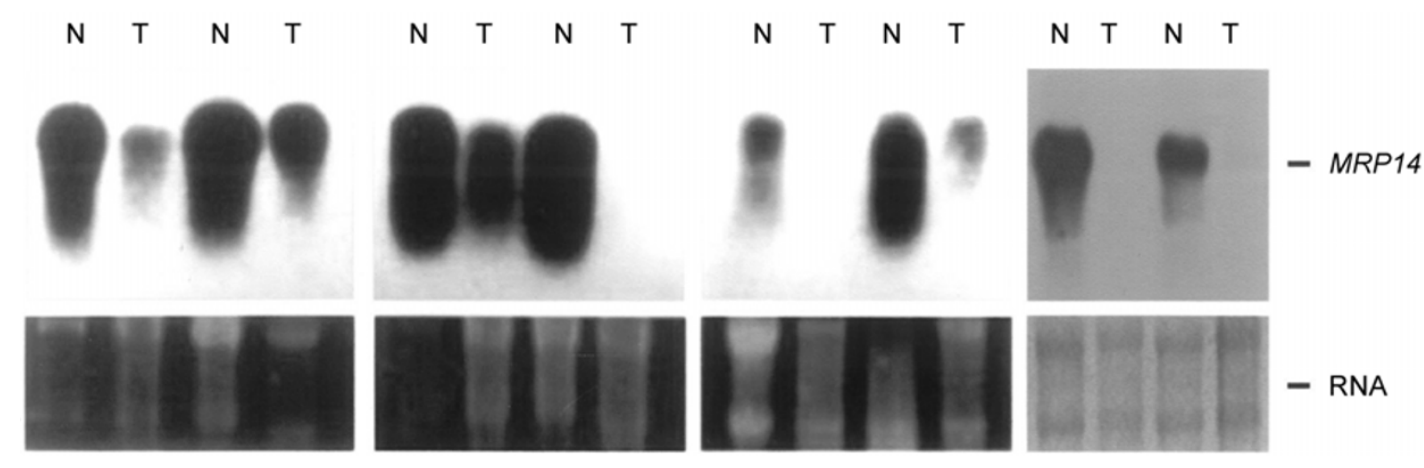

Fig 1. mRNA differential display of three esophageal carcinomas $(\mathrm{T})$ and matched adjacent esophageal mucosa $(\mathrm{N})$. Arrow indicates the recovered band. M- $\phi$ X174 DNA/HaeIII marker.

Fig 2. Northern blot analysis of MRP14 in matched esophageal carcinomas (T) and adjacent histologically normal tissues $(\mathrm{N})$.

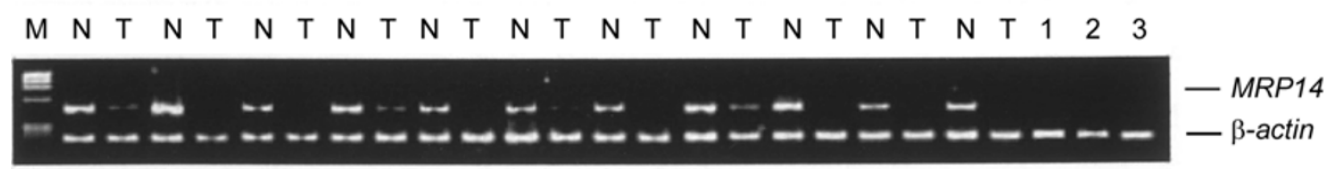

Fig 3. Representative RT-PCR analysis of MRP14 in matched esophageal carcinomas (T) and adjacent histologically normal tissues (N). 1-3: Esophageal cancer cell lines EC109, EC8712 and EC9706; M-фX174 DNA/HaeIII marker. 
Tab 1. Basic clinical data and MRP14 expression analysis of 66 esophageal tumors

\begin{tabular}{|c|c|c|c|c|c|c|c|c|c|}
\hline No. & Sample source ${ }^{\mathrm{a}}$ & Sex & Age & $\begin{array}{l}\text { Tumor } \\
\text { type }^{b}\end{array}$ & TNM & & Grade & $\begin{array}{l}\text { MRP14 } \\
\text { eduction }\end{array}$ & $\begin{array}{l}\text { Analysis } \\
\text { method }^{c}\end{array}$ \\
\hline 1 & $\mathrm{H}$ & M & 67 & $\mathrm{AC}$ & T3N1M0 & III & G2 & Yes & DD, RT-PCR \\
\hline 2 & $\mathrm{H}$ & M & 49 & $\mathrm{SC}$ & T3N0M0 & IIa & $\mathrm{G} 2$ & Yes & RT-PCR \\
\hline 3 & $\mathrm{H}$ & $\mathrm{F}$ & 65 & SC & T3N0M0 & IIa & G3 & Yes & RT-PCR \\
\hline 4 & $\mathrm{H}$ & $\mathrm{F}$ & 50 & $\mathrm{SC}$ & T3N0M0 & IIa & $\mathrm{G} 2$ & Yes & RT-PCR \\
\hline 5 & $\mathrm{H}$ & M & 70 & SC & T3N1M0 & III & $\mathrm{G} 3$ & Yes & DD, RT-PCR \\
\hline 6 & $\mathrm{H}$ & M & 58 & SC & T2N1M0 & IIa & G3 & Yes & RT-PCR \\
\hline 7 & $\mathrm{H}$ & $\mathrm{F}$ & 58 & SC & T2N1M0 & $\mathrm{IIb}$ & $\mathrm{G} 2$ & Yes & RT-PCR \\
\hline 8 & $\mathrm{H}$ & M & 58 & SC & T3N0M0 & IIa & $\mathrm{G} 2$ & Yes & RT-PCR \\
\hline 9 & $\mathrm{H}$ & M & 47 & SC & T3N1M0 & III & $\mathrm{G} 2$ & Yes & RT-PCR \\
\hline 10 & $\mathrm{H}$ & $\mathrm{F}$ & 50 & SC & T2N1M0 & $\mathrm{IIb}$ & $\mathrm{G} 2$ & Yes & RT-PCR \\
\hline 11 & $\mathrm{H}$ & M & 64 & SC & T3N1M0 & III & G3 & Yes & RT-PCR \\
\hline 12 & $\mathrm{H}$ & M & 49 & SC & T3N0M0 & IIa & $\mathrm{G} 2$ & Yes & RT-PCR \\
\hline 13 & $\mathrm{H}$ & $\mathrm{F}$ & 67 & SC & T2N0M0 & IIa & $\mathrm{G} 1$ & Yes & DD, RT-PCR \\
\hline 14 & $\mathrm{~L}$ & $\mathrm{~F}$ & 47 & SC & T3N0M0 & IIa & $\mathrm{G} 1$ & No & RT-PCR \\
\hline 15 & $\mathrm{~L}$ & M & 60 & SC & T3N1M0 & III & $\mathrm{G} 1$ & Yes & RT-PCR \\
\hline 16 & $\mathrm{~L}$ & $\mathrm{~F}$ & 62 & SC & T3N0M0 & IIa & $\mathrm{G} 2$ & Yes & N, RT-PCR \\
\hline 17 & $\mathrm{~L}$ & $\mathrm{M}$ & 63 & $\mathrm{SC}$ & T3N0M0 & IIa & $\mathrm{G} 2$ & Yes & RT-PCR \\
\hline 18 & $\mathrm{~L}$ & $\mathrm{~F}$ & 60 & SC & T3N0M0 & IIa & $\mathrm{G} 2$ & Yes & RT-PCR \\
\hline 19 & $\mathrm{~L}$ & M & 45 & SC & T3N0M0 & IIa & $\mathrm{G} 1$ & No & RT-PCR \\
\hline 20 & $\mathrm{~L}$ & M & 40 & SC & T3N1M0 & III & $\mathrm{G} 1$ & Yes & RT-PCR \\
\hline 21 & $\mathrm{~L}$ & M & 75 & SC & T3N0M0 & IIa & $\mathrm{G} 1$ & Yes & RT-PCR \\
\hline 22 & $\mathrm{~L}$ & $\mathrm{~F}$ & 55 & $\mathrm{AC}$ & T3N1M0 & III & $\mathrm{G} 2$ & Yes & RT-PCR \\
\hline 23 & $\mathrm{~L}$ & M & 66 & SC & T3N1M0 & III & $\mathrm{G} 1$ & Yes & N, RT-PCR \\
\hline 24 & $\mathrm{~L}$ & M & 60 & SC & T3N1M0 & III & $\mathrm{G} 1$ & Yes & RT-PCR \\
\hline 25 & $\mathrm{~L}$ & $\mathrm{~F}$ & 53 & SC & T3N0M0 & IIa & G3 & Yes & RT-PCR \\
\hline 26 & $\overline{\mathrm{L}}$ & M & 64 & SC & T3N1M0 & III & G3 & Yes & N, RT-PCR \\
\hline 27 & $\mathrm{~L}$ & $\mathrm{M}$ & 56 & SC & T3N1M0 & III & $\mathrm{G} 2$ & Yes & RT-PCR \\
\hline 28 & $\mathrm{~L}$ & M & 45 & SC & T3N1M0 & III & G3 & Yes & RT-PCR \\
\hline 29 & $\mathrm{~L}$ & M & 50 & SC & T3N0M0 & IIa & $\mathrm{G} 1$ & Yes & RT-PCR \\
\hline 30 & $\mathrm{~L}$ & M & 71 & SC & T3N0M0 & IIa & G1 & Yes & N, RT-PCR \\
\hline 31 & $\mathrm{~L}$ & M & 38 & SC & T3N0M0 & IIa & $\mathrm{G} 2$ & Yes & N, RT-PCR \\
\hline 32 & $\mathrm{~L}$ & M & 50 & SC & T3N1M0 & III & $\mathrm{G} 2$ & Yes & RT-PCR \\
\hline 33 & $\mathrm{~L}$ & M & 58 & SC & T3N1M0 & III & $\mathrm{G} 2$ & Yes & RT-PCR \\
\hline 34 & $\mathrm{~L}$ & $\mathrm{M}$ & 54 & SC & T3N1M0 & III & $\mathrm{G} 1$ & No & RT-PCR \\
\hline 35 & $\mathrm{~L}$ & $\mathrm{M}$ & 54 & SC & T2N0M0 & IIa & $\mathrm{G} 1$ & Yes & RT-PCR \\
\hline 36 & $\mathrm{~L}$ & $\mathrm{~F}$ & 50 & SC & T2N1M0 & $\mathrm{IIb}$ & $\mathrm{G} 1$ & Yes & RT-PCR \\
\hline 37 & $\mathrm{~L}$ & $\mathrm{~F}$ & 59 & SC & T2N0M0 & IIa & $\mathrm{G} 1$ & Yes & N, RT-PCR \\
\hline 38 & $\mathrm{~L}$ & M & 70 & SC & T3N1M0 & III & $\mathrm{G} 2$ & Yes & RT-PCR \\
\hline 39 & $\mathrm{~L}$ & M & 49 & SC & T2N1M0 & $\mathrm{IIb}$ & $\mathrm{G} 3$ & Yes & RT-PCR \\
\hline 40 & $\mathrm{~L}$ & M & 52 & SC & T3N0M0 & IIa & $\mathrm{G} 1$ & No & RT-PCR \\
\hline 41 & $\mathrm{~L}$ & M & 51 & SC & T3N1M0 & III & $\mathrm{G} 2$ & Yes & RT-PCR \\
\hline 42 & $\mathrm{~L}$ & M & 38 & SC & T4N1M0 & III & $\mathrm{G} 3$ & Yes & RT-PCR \\
\hline 43 & $\mathrm{~L}$ & $\mathrm{~F}$ & 50 & SC & T3N0M0 & IIa & $\mathrm{G} 1$ & Yes & RT-PCR \\
\hline 44 & $\mathrm{~L}$ & M & 55 & SC & T4N1M0 & III & $\mathrm{G} 2$ & Yes & RT-PCR \\
\hline 45 & $\mathrm{~L}$ & M & 70 & $\mathrm{SC}$ & T3N1M0 & III & $\mathrm{G} 3$ & Yes & RT-PCR \\
\hline 46 & $\mathrm{~L}$ & M & 72 & SC & T3N0M0 & IIa & $\mathrm{G} 1$ & Yes & RT-PCR \\
\hline 47 & $\mathrm{~L}$ & M & 48 & SC & T3N1M0 & III & G2 & Yes & RT-PCR \\
\hline 48 & $\mathrm{~L}$ & $\mathrm{M}$ & 65 & SC & T4N1M0 & III & $\mathrm{G} 2$ & Yes & RT-PCR \\
\hline 49 & $\mathrm{~L}$ & M & 63 & SC & T3N1M0 & III & $\mathrm{G} 2$ & Yes & RT-PCR \\
\hline 50 & $\overrightarrow{\mathrm{L}}$ & M & 62 & SC & T3N0M0 & IIa & $\mathrm{G} 1$ & Yes & RT-PCR \\
\hline 51 & $\mathrm{~L}$ & M & 56 & SC & T3N0M0 & IIa & G3 & Yes & RT-PCR \\
\hline 52 & $\mathrm{~L}$ & M & 55 & SC & T3N0M0 & IIa & $\mathrm{G} 1$ & Yes & RT-PCR \\
\hline 53 & $\overline{\mathrm{L}}$ & $\mathrm{M}$ & 68 & SC & T3N1M0 & III & $\mathrm{G} 1$ & Yes & RT-PCR \\
\hline 54 & $\mathrm{~L}$ & M & 64 & SC & T3N0M0 & IIa & $\mathrm{G} 1$ & No & RT-PCR \\
\hline 55 & $\mathrm{~L}$ & M & 60 & SC & T4N0M0 & III & $\mathrm{G} 2$ & Yes & RT-PCR \\
\hline 56 & $\overline{\mathrm{L}}$ & $\mathrm{F}$ & 73 & SC & T3N0M0 & IIa & $\mathrm{G} 2$ & Yes & RT-PCR \\
\hline 57 & $\mathrm{~L}$ & M & 47 & SC & T3N1M0 & III & $\mathrm{G} 1$ & No & RT-PCR \\
\hline 58 & $\mathrm{~L}$ & $\mathrm{~F}$ & 57 & SC & T3N0M0 & IIa & $\mathrm{G} 2$ & Yes & RT-PCR \\
\hline 59 & $\mathrm{~L}$ & M & 67 & SC & T4N1M0 & III & $\mathrm{G} 1$ & Yes & RT-PCR \\
\hline 60 & $\mathrm{~L}$ & M & 40 & SC & T2N1M0 & $\mathrm{IIb}$ & $\mathrm{G} 2$ & Yes & RT-PCR \\
\hline 61 & $\bar{L}$ & $\mathrm{M}$ & 78 & SC & T3N0M0 & IIa & $\mathrm{G} 2$ & Yes & $\mathrm{N}$ \\
\hline 62 & $\mathrm{~L}$ & M & 64 & SC & T3N0M0 & IIa & - & Yes & $\mathrm{N}$ \\
\hline $6 \overline{3}$ & $\overline{\mathrm{L}}$ & $\mathrm{M}$ & 55 & SC & T3N1M0 & III & G2 & Yes & W \\
\hline 64 & $\mathrm{~L}$ & M & 64 & SC & T3N1M0 & III & $\mathrm{G} 1$ & Yes & $\mathrm{W}$ \\
\hline 65 & $\mathrm{~L}$ & $\mathrm{M}$ & 77 & SC & $\mathrm{T} 2 \mathrm{~N} 1 \mathrm{M} 0$ & $\mathrm{IIb}$ & - & Yes & W \\
\hline 66 & $\mathrm{~L}$ & $\mathrm{M}$ & 56 & SC & T3N0M0 & IIa & G1 & Yes & W \\
\hline
\end{tabular}

Notes: ${ }^{a} \mathrm{H}$-high incidence area of Anyang, Henan province, China, L-low incidence area of Beijing, China, respectively; ${ }^{\text {bSC-squamous cell }}$ carcinomas, AC-adenocarcinomas; ${ }^{\mathrm{c}} \mathrm{DD}$-differential display, N-Northern blot, W-Western blot. 

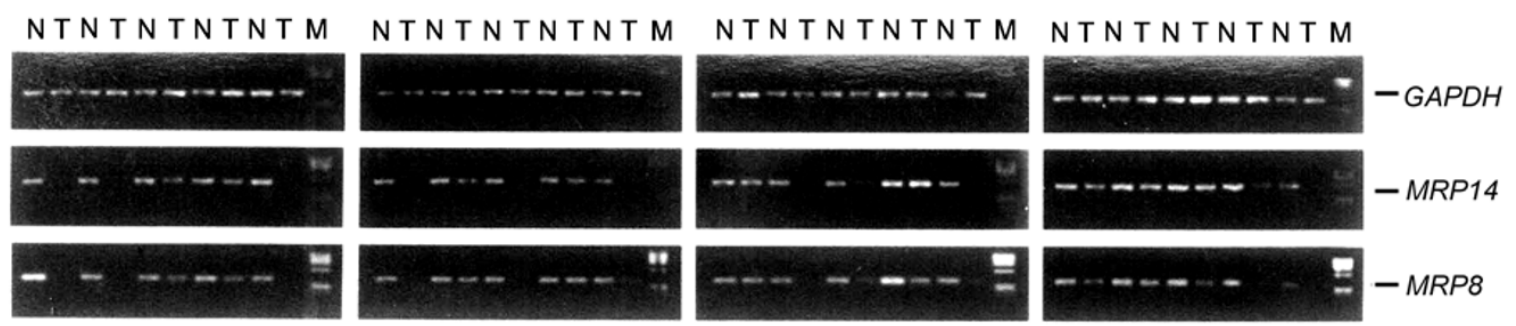

Fig 4. Simultaneous RT-PCR analysis of both MRP14 and MRP8 in matched esophageal carcinomas (T) and adjacent histologically normal tissues (N). M- $\phi X 174$ DNA/HaeIII marker.

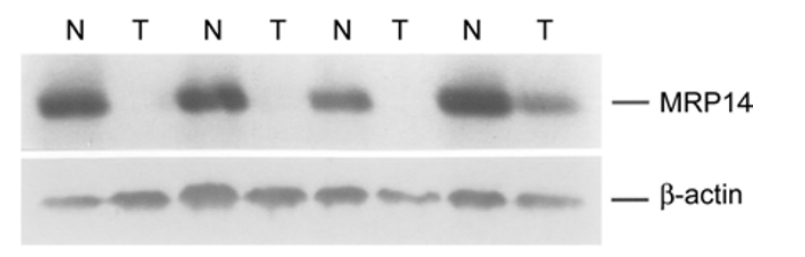

Fig 5. Decreased expression of MRP14 protein in esophageal cancer confirmed by Western blotting. Four cases of esophageal cancerous $(\mathrm{T})$ and matched normal tissues $(\mathrm{N})$ were analyzed using a polyclonal antibody against MRP14. Normalization of protein load was performed using an anti- $\beta$-actin antibody.
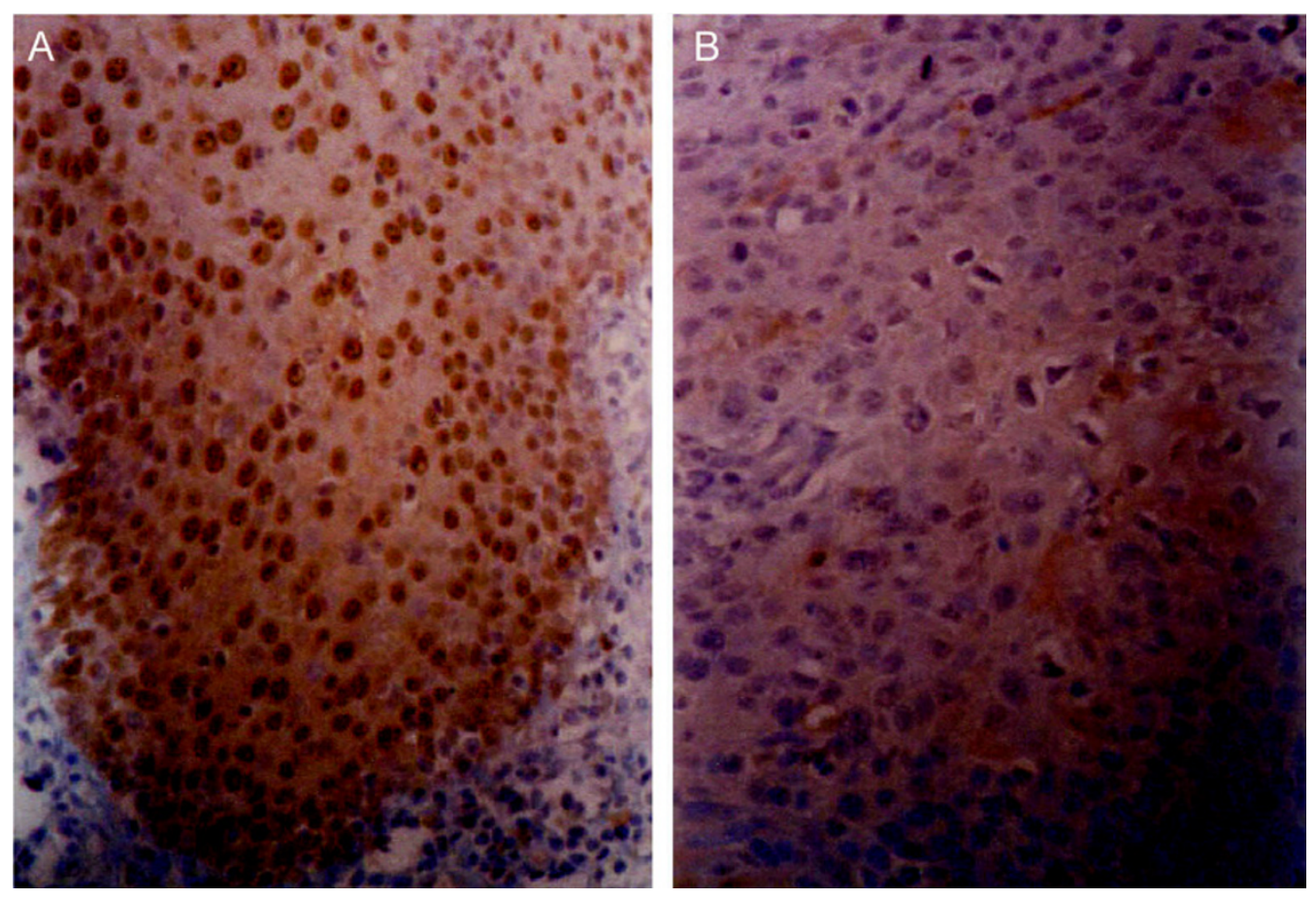

Fig 6. Immunohistochemistry staining of MRP14. Note that MRP14 (brown) highly expressed in histologically normal esophageal epithelium (A), but feebly stained in tumor tissues (B). 125×.

\section{Expression of MRP14 were frequently decreased in esophageal cancer}

For confirming the results from differential display and the repression of MRP14 in esophageal cancer, we carried out a pilot Northern-blot assay. The hybridization probe was prepared by PCR with the same primers as used in reverse transcription - polymerase chain reaction. Northern blotting showed that MRP14 were preferentially expressed in $8 / 8$ normal esophageal tissues and dramatically down-regulated in all the carcinoma counterparts (Fig 2).

The results of Northern blotting prompted us to further analyze the clinical significance of the MRP14 gene by reverse transcription - polymerase chain reaction (RTPCR). Of the samples tested, 52/58 squamous cell carcinomas and $2 / 2$ adenocarcinomas presented a decrease expression in comparison with the adjacent normal mucosa (Tab 1, Fig 3). MRP14 was undetectable in 3/3 esophagealcarcinoma cell lines. There was no statistically significant 
correlation between MRP14 expression and gender, age, tumor grade or stage, and lymph node metastases. In addition, 20 pairs of cancer/normal tissues were analyzed by RT-PCR of both MRP14 and MRP8. Simultaneous down-regulation of these two genes was observed in 16 cases of tumors (Fig 4).

Western blot analysis was performed in four esophageal tumors and matched normal epithelia. Complete or substantial loss of MRP14 was observed in all four tumors examined, whereas in the adjacent normal epithelium, MRP14 presented high expression (Fig 5). Putting together the results from differential display, RT-PCR, Northern blot and Western blot analysis, MRP14 expression was lost in 3/3 esophageal-carcinoma cell lines and decreased dramatically in 60/66 esophageal carcinomas compared to normal tissues.

Immunohistochemistry showed that MRP14 expressed in normal esophageal epithelia adjacent to tumor tissue, especially with strong staining in the nuclei (Fig 6). No signal was detected in connective cells and muscle cells. Esophageal tumor tissues presented no or very feeble staining, thus confirmed that expression of MRP14 was reduced in esophageal cancer as identified by Northern blot and RT-PCR analysis.

\section{No genomic mutation was detected for MRP14 in tumor tissues and carcinoma cell line of the esophagus}

In order to investigate possible mutations of the promotor region, the first exon and the enhancer (a part of the first intron) of the MRP14 gene[11], 18 esophageal tumors/matched normal epithelia, the esophageal carcinoma cell line EC9706 and human placenta (as control) were analyzed by PCR and directed DNA sequencing. No mutation was found in the $-489 \sim 512$ bp range of the MRP14 gene of all the tumors and in the whole MRP14 genomic sequence of the EC9706.

\section{DISCUSSION}

MRP14 is a member of the S100 family of calciumbinding proteins. It is referred variously as S100A9, P14, calgranulin B (GAGB), calprotectin, cystic fibrosis antigen or L1 heavy chain. MRP14 is frequently companied with another calcium-binding protein, MRP8 (S100A8, calgranulin A, GAGA or L1 light chain), forming specific MRP8/P14 heterodimeric complex by chemical crosslinking. This complex has been shown to inhibit the activity of casein kinase I and II[12]. Recent studies suggest that MRP8/P14 complex is the major fatty acid (FA) carrier in human neutrophils[13].

The expression of MRP8 and MRP14 is involved in monocyte/macrophage differentiation. In peripheral blood, the proteins MRP8 and MRP14 are only observed in granulocytes and monocytes[14]. Elevated plasma levels of MRP8 and MRP14 have been found in patients suffering from a number of inflammatory disorders including cystic fibrosis, rheumatoid arthritis, and chronic bronchitis. In all (acute and chronic) inflammation models tested, the cells arriving first at the lesion were MRP8/MRP14-positive[15].

Little information is available concerning the implication of MRP14 in human cancer. Down-regulation of MRP8 and MRP14 was observed in human lung carcinoma cell lines[16]. Endress et al. investigated 35 lung carcinomas and 5 healthy lungs with the antibodies recognizing different macrophage subtypes. Compared to healthy lungs, the infiltration of MRP8/MRP14-positive macrophages was reduced in lung carcinomas while the number of MRP8/MRP14 - positive cells was enhanced [17]. Stulik et al. analyzed the expression pattern of MRP8 and MRP14 in 23 matched sets of colorectal carcinomas and normal colon mucosa using two-dimensional gel electrophoresis. They found that the level of these two proteins, as compared with matched normal colon mucosa, was significantly increased in malignant tissues of 16 patients (70\%). The immunohistological analysis revealed the accumulation of MRP14 positive cells, macrophages and polymorphonuclear leukocytes along the invasive margi of co-lorectal carcinoma[18]. Quite the contrary, esophageal cancer presented a decreased expression of MRP14 compared to normal mucosa.

In the present study, MRP14 expression was undetectable in 3/3 esophageal-carcinoma cell lines. 58 out of 64 primary squamous cell carcinomas of the esophagus presented markedly lower expression of MRP14 than the corresponding normal tissues. These data indicated that down-regulation of MRP14 expression is a frequent event in esophageal squamous cell carcinomas. No statistically significant correlations were found between MRP14 expression and gender, age, tumor grade or stage, and lymph node metastases. Nevertheless, all the six tumors without alteration of MRP14 expression presented cytologically grade I (G1). On the other hand, the samples examined were from two different regions of China: esophageal cancer high-incidence area, Anyang, Henan province, and lowincidence area, Beijing. Compared to the down-regulation rates of MRP14 between the two different regions, no significant difference was found. Dietary factors, nitrosamine exposure and history of injury to the esophagus have been reported to somehow associated with the high incidence of this malignancy in North China[19, 20]. However, consistent high down-regulation rates of MRP14 in the two different areas indicated that abnormality of MRP14 gene might not be a downstream event contrib- 
uted by the environmental and chemical risk factors found in the high-incidence area. Although the significance of MRP14 in esophageal cancer remains unclear, the reverse alteration of MRP14 expression in the disease, as compared to colorectal carcinomas, suggested that different molecular mechanisms might be involved regarding to the implication of MRP14 in the development or progression of these two kinds of tumors. Interestingly, we found that MRP8, like MRP14, was simultaneously down-regulated in esophageal cancer. It will be important to further investigate the precise role of these two genes in the development and progression of esophageal squamous cell carcinomas. It is noted that MRP14 was down-expressed in $2 / 2$ esophageal adenocarcinomas, which leaves open the question of whether the repression of MRP14 was also involved in esophageal adenocarcinomas.

MRP8/MRP14 proteins present a variant subcellular localization in different types of cells. In monocytes, MRP8/ MRP14 associate with the type III intermediate filament vimentin of cytoskeletal structures in a $\mathrm{Ca}^{2+}$-dependent manner[21]. Buccal squamous carcinoma cell line TR146 displays a localization of MRP8/MRP14 in keratin intermediate filaments[22]. In the pancreatic cell lines, MRP8/ MRP14 remains in the cytoplasm or in the plasma membrane, depending on the functional status of the cells [23]. We found that in normal esophageal mucosa, MRP14 expressed predominantly in the nuclei of the epithelial cells. This subcellular localization different from previous reports suggests MRP14 probably play a particular role in normal epithelial cells of the esophagus.

To investigate the mechanism of MRP14 expression reduction in esophageal carcinomas, we sequenced the full-length genomic DNA of the MRP14 gene in esophageal cancer cell line EC9706 and human placenta (as control). Neither of mutation, deletion or rearrangement was found in the cell line EC9706. Then we analyzed the promotor region, the first exon and the enhancer (a part of the first intron) of the MRP14 gene in 18 esophageal tumors and matched normal epithelial tissues. No mutation was detected in the -489 512 bp range of the MRP14 gene of all the tumors. The results suggested possible involvement of epigenetic abnormalities in esophageal cancer, to which further studies should be addressed.

\section{ACKNOWLEDGMENTS}

This work was supported by State Key Basic Research programme of China (G1998051205), National Key Technologies R\&D Programme of China (2002BA711A06), The National High Technology Research and Development Program of China (2001AA221151), National Natural Science Foundation of China (30125026), and Doctoral Program Fund of China (20010023016).
Received, May 6, 2003

Revised, Dec 8, 2003

Accepted, Jan 5, 2004

\section{REFERENCES}

1 Parkin DM, Pisani P, Ferlay J. Estimates of the worldwide incidence of eighteen major cancers in 1985. Int J Cancer 1993; 55: 891-903.

2 Li L, Lu FZ, Zhang SW, Mu R, Sun XD, Huangpu XM, et al. Epidemiological analysis of Chinese malignant tumor death during 1990-1992. Chin J Oncol 1996; 18:403-7.

3 Montesano R, Hollstein M, Hainaut P. Genetic alterations in esophageal cancer and their relevance to etiology and pathogenesis: a review. Int J Cancer 1996; 69:225-35.

4 Muzeau F, Fléjou JF, Thomas G, Hamelin R. Loss of heterozygosity on chromosome 9 and p16 (MTS1, CDKN2) gene mutations in esophageal cancers. Int J Cancer 1997; 72:27-30.

5 Roncalli M, Bosari S, Marchetti A Buttitta, F Bossi, P Graziani D Peracchia, A Bonavina L, et al. Cell cycle-related gene abnormalities and product expression in esophageal carcinoma. Lab Invest 1998; 78:1049-57.

6 Xing EP, Yang GY, Wang LD, Shi ST, Yang CS. Loss of heterozygosity of the $\mathrm{Rb}$ gene correlates with $\mathrm{pRb}$ protein expression and associates with $\mathrm{p} 53$ alteration in human esophageal cancer. Clin Cancer Res 1999; 5:1231-40.

7 Li S, Zhang L, Luo X, Ao P. Cytogenetic studies on three esophageal cancer cell lines. Chin J Oncol 1987; 9:90-4.

8 Wang X, Xiao F, Wang M, Zhou C, Wu M. Establishment of two human esophageal carcinoma cell lines and their cytogenetic analysis. Chin J Oncol 1998; 20:5-8.

9 Han YL, Wei F, Xu X, Cai Y, Chen BS, Wang J, et al. Establishment and comparative genomic hybridization analysis of human esophageal carcinomas cell line EC9706. Chin J Med Genet 2002; 19:455-7.

10 Liang P, Pardee AB. Differential display of eukaryotic messenger RNA by means of the polymerase chain reaction. Science 1992; 257:967-71.

11 Melkonyan H, Hofmann HA, Nacken W, Sorg C, Klempt M. The gene encoding the myeloid-related protein 14 (MRP14), a calcium-binding protein expressed in granulocytes and monocytes, contains a potent enhancer element in the first intron. J Biol Chem 1998; 273:27026-32.

12 Murao S, Collart FR, Huberman E. A protein containing the cystic fibrosis antigen is an inhibitor of protein kinases. J Biol Chem 1989; 264:8356-60.

13 Roulin K, Hagens G, Hotz R, Saurat JH, Veerkamp JH, Siegenthaler G. The fatty acid-binding heterocomplex FA-p34 formed by S100A8 and S100A9 is the major fatty acid carrier in neutrophils and translocates from the cytosol to the membrane upon stimulation. Exp Cell Res 1999; 247:410-21.

14 Zwadlo G, Bruggen J, Gerhards G, Schlegel R, Sorg C. Two calcium-binding proteins associated with specific stages of myeloid cell differentiation are expressed by subsets of macrophages in inflammatory tissues. Clin Exp Immunol 1988; 72:510-5.

15 Sorg C. The calcium binding proteins MRP8 and MRP14 in acute and chronic inflammation. Behring Inst Mitt 1992; 91:12637.

16 Hellmann GM, Fields WR, Doolittle DJ. Gene expression pro- 
filing of cultured human bronchial epithelial and lung carcinoma cells. Toxicol Sci 2001; 61:154-63.

17 Endress H, Freudenberg N, Fitzke E, Grahmann PR, Hasse J, Dieter P. Infiltration of lung carcinomas with macrophages of the 27E10-positive phenotype. Lung Cancer 1997; 18:35-46.

18 Stulik J, Osterreicher J, Koupilova K, Knizek J, Macela A, Bures $\mathrm{J}$, et al. The analysis of S100A9 and S100A8 expression in matched sets of macroscopically normal colon mucosa and colorectal carcinoma: the S100A9 and S100A8 positive cells underlie and invade tumor mass. Electrophoresis 1999; 20:104754.

19 Lu SH, Ohshima H, Fu HM, Tian Y, Li FM, Blettner M, et al. Urinary excretion of N-nitrosamino acids and nitrate by inhabitants of the high and low-risk areas for esophageal cancer in North China: endogenous formation of nitrosoproline and its inhibition by vitamin C. Cancer Res 1986; 46:1485-91.

20 Li JY, Taylor PR, Li B, Dawsey S, Wang GQ, Ershow AG, et al.
Nutrition intervention trials in Lixian, China: multiple vitamine/ mineral supplementation, cancer incidence and disease-specific mortality among adults with esophageal dysplasia. J Natl Cancer Inst 1993; 85:1492-8.

21 Burwinkel F, Roth J, Goebeler M, Bitter U, Wrocklage V, Vollmer E, et al. Ultrastructural localization of the S-100-like proteins MRP8 and MRP14 in monocytes is calcium-dependent. Histochemistry 1994; 101:113-20.

22 Goebeler M, Roth J, van den Bos C, Ader G, Sorg C. Increase of calcium levels in epithelial cells induces translocation of calciumbinding proteins migration inhibitory factor-related protein 8 (MRP8) and MRP14 to keratin intermediate filaments. Biochem J 1995; 309:419-24.

23 Fanjul M, Renaud W, Merten M, Guy-Crotte O, Hollande E, Figarella C. Presence of MRP8 and MRP14 in pancreatic cell lines: differential expression and localization in CFPAC-1 cells. Am J Physiol 1995; 268:C1241-51. 